\title{
Educação linguística e formação de professores de inglês
}

\section{Educational Linguistics and English Language Teacher Education}

Débora Balsemão Oss*

Universidade do Vale do Rio dos Sinos

Caxias do Sul - Rio Grande do Sul - Brasil

RESUMO: Este artigo parte da necessidade de compreender mais aprofundadamente os aspectos relacionados à educação linguística, suas origens e suas aplicações na formação de professores de inglês. Ao partir da premissa de que o tema é pouco explorado nos programas de ensino que visam à preparação para a carreira docente, propôs-se o presente estudo, que contou com a colaboração de 28 professores licenciados em Letras, com experiência ou com formação no ensino de língua inglesa, ou que atuam como docentes de línguas ou que tenham pós-graduação na área do ensino de línguas (mestres ou doutores). Os objetivos específicos do estudo - (i) detectar se o conceito de Linguística Educacional fez parte da formação dos professores para, então, (ii) propor uma reflexão acerca das práticas formativas relacionadas à educação linguística dos futuros docentes de línguas, particularmente de professores de inglês - foram alcançados a partir da análise dos resultados dos dados e da revisão bibliográfica que refere à Linguística Educacional, subárea da Linguística Aplicada que dá conta das questôes relacionadas à educação linguística.

PALAVRAS-CHAVE: linguística educacional; educação linguística; formação de professores de línguas.

ABSTRACT: This article originated from the need to understand aspects related to language education, its origins, and its applications. The premise that language education is underexplored in language teacher education programs was the starting point for this investigation. In order to address the study, a brief survey was answered by 28 participants who are either experienced or who have majored in English language teaching (ELT) or who teach languages or hold a postgraduation degree in the area. The specific objectives of the study - (i) to learn whether the concept of Educational Linguistics was part of the participants' ELT learning programs in order (ii) to propose a reflection on educational practices of language teachers-to-be, particularly ELTeachers - were met after the analysis of data, supported by the bibliographical review on Educational Linguistics, subarea of Applied Linguistics, which addresses issues related to language education.

KEYWORDS: educational linguistics; language education; ELT education.

*debora.oss@gmail.com 


\section{Introdução}

A Linguística Aplicada, como campo investigativo independente e imbuído do diálogo teórico e prático com áreas das ciências sociais e humanas, opera a partir de uma concepção interdisciplinar, inerente à sua natureza. Ao partir da sua essência, a pesquisa em Linguística Aplicada (LA) contemporânea se ocupa da problematização de questôes relacionadas ao uso da linguagem como prática social, ou seja, como os aspectos históricos, políticos e socioculturais da atualidade se inter-relacionam e se reorganizam com vistas à elaboração de novas formas de teorizar e de praticar a LA (MOITA LOPES, 2006). Assim, e porque a LA se constitui a partir de um universo formado por contextos em permanente mudança, o uso da linguagem precisa ser compreendido tanto da perspectiva de fora quanto de dentro da sala de aula (CAVALCANTI, 1986).

Com esse entendimento em mente, o presente estudo parte da premissa de que as concepções que formulam "a interação da educação formal com a língua" (SPOLSKY, 1974b) têm papel fundamental na formação dos futuros professores de línguas e, portanto, carecem de uma abordagem mais explícita, com vistas à valorização da terminologia (BOLITHO, 1998), ao comprometimento com a educação linguística dos futuros professores de línguas (BARTELS, 2005) e, em última análise, ao engajamento com a própria profissão.

Através deste texto, portanto, pretendo atingir dois grupos de leitores em especial. O primeiro, os colegas professores formadores de futuros colegas envolvidos no ensino de língua inglesa, minha área de atuação; o segundo, os acadêmicos dos cursos de Letras-Inglês, também sujeitos com os quais conquistas profissionais são compartilhadas.

Ao primeiro grupo, pretendo simplesmente apresentar o resultado de uma breve investigação que fiz com colegas envolvidos com a aprendizagem e/ou com o ensino de inglês em diferentes contextos sobre o tema Educational Linguistics, ou, em português, Linguística Educacional. Com o segundo grupo, minha intenção é de chamamento. Espero, sinceramente, que dentro de alguns anos possamos reeditar esta singela investigação e obter resultados que deem conta de ações significativas quanto à aprendizagem crítica de línguas e de um ensino comprometido com temas tão essenciais para nossas práticas. Como professora de inglês e como formadora de futuros colegas, penso que a presente contribuição pode lançar luzes sobre a elaboração dos currículos desenvolvidos com vistas à formação destes profissionais da educação. Além disso, o papel do professor universitário se consolida a partir do momento em que 
compartilhamos o compromisso que nos é imbuído de promover e apoiar o espírito investigativo em cada aluno, futuro colega, através de atitudes críticas e linguisticamente informadas.

A fim de apresentar as ideias que originaram este estudo, na primeira parte do artigo introduzo e contextualizo o leitor quanto às áreas que se dedicam às manifestações das linguagens humanas e a alguns de seus desmembramentos, tendo o acadêmico de Letras-Inglês em mente. Além disso, a fundamentação teórica e os exemplos selecionados têm também o objetivo de servir de autorreflexão da nossa parte - professores formadores -, quanto ao papel da LA e da instrução explícita dos seus princípios norteadores e, particularmente, da Linguística Educacional. Na segunda parte do artigo discorro mais pormenorizadamente sobre o estudo, apresentando o perfil dos colaboradores e os instrumentos que serviram de ferramentas de apoio na geração dos dados. Finalmente, após proceder à análise dos dados, apresento as reflexões decorrentes das contribuições dos colegas que participaram do estudo.

\section{A ciência das línguas}

Como ciência, ou como um "conjunto de conhecimentos sistematizados, relativos a uma ordem de fenômenos” (LUFT, 1996, 137), a linguística também pode ser entendida como o "estudo da língua como um sistema de comunicação humana” (RICHARDS, PLATT e PLATT, 1992). Objetivamente, os cientistas das línguas e das linguagens são os linguistas, estudiosos que dão conta das manifestações verbais humanas. Esses estudiosos estão, portanto, interessados em descrever e em explicar tais manifestaçóes do ponto de vista científico, utilizando critérios para gerar dados, organizá-los, selecioná-los e analisá-los a partir de quadros teóricos que amparem as suas investigações sobre o funcionamento das línguas. Isso é, em linhas muito gerais, o objeto de estudo da ciência das línguas humanas, ou seja, a Linguística.

Através de estudos metodizados, a Linguística pode estudar os constituintes da língua, como os aspectos fonológicos (os fonemas), os morfológicos (as formas das palavras), os sintáticos (as funções das palavras) e semânticos (os sentidos das palavras ou frases). Além disso, dependendo do foco de análise, a ciência das línguas humanas pode descrever mudanças que determinada língua sofreu com o passar do tempo (Linguística Histórica ou Diacrônica) ou como manifestações linguísticas ocorriam em algum momento específico da história de comunidades linguísticas (Linguística Descritiva ou Sincrônica), por exemplo. 
Além desses, de ênfase descritiva, os estudos linguísticos também contemplam aspectos relacionados à teorização sobre as línguas, ou seja, à busca por respostas sobre como os fenômenos linguísticos ocorrem em diferentes contextos, isto é, à Linguística cabe investigar as linguagens como expressão do pensamento - via palavra, via escrita ou via sinais -, e não somente as línguas como sistema de comunicação comum a uma comunidade linguística. Ao incluir o contexto, a Linguística também pode estudar os papéis dos interagentes e do espaço de interação em si, seja do ponto de vista da aquisição da língua pelo indivíduo (Psicolinguística), dos processos mentais envolvidos na aprendizagem de línguas (Linguística Cognitiva), ou da perspectiva social e das relaçôes de usos que os falantes fazem em diferentes contextos (Sociolinguística), entre outros (HUDSON, 2008; HULT, 2008; LOPESROSSI, 2009; RODRIGUES, 1966).

Conforme delineado, pode-se observar que os estudos das línguas humanas se ocupam de áreas diversas, abordando aspectos mais diretamente relacionados ao respectivo escopo investigativo - se descritivo, se histórico, se psicológico, se cognitivo, se social, etc. Desta perspectiva, depreende-se o caráter multidisciplinar necessariamente associado a essa área do conhecimento, bem como a gama de questôes intrinsecamente relacionadas às interaçôes dos sujeitos, dos grupos sociais, das diferentes comunidades linguísticas e das respectivas disputas decorrentes. Para tratar de tais questôes, cabe à LA relacionar-se com campos como o da antropologia, o da computação, o da educação, entre outros, para atender a demandas cujo interesse seja "criar inteligibilidade sobre problemas sociais em que a linguagem tem um papel central” (MOITA LOPES, 2006, p. 14). Na perspectiva em que este texto se situa, a relação que se estabelece é com o campo da educação/formação de professores de língua inglesa.

\section{A LA e a formação de professores de línguas}

Ao retomar o objetivo da seção anterior - informar o leitor sobre alguns dos itens sobre os quais os cientistas da língua se debruçam -, penso ser relevante compartilhar com os acadêmicos recém-chegados aos cursos de Letras a importância dos estudos acerca de conhecimentos sistematizados que conduzem ao entendimento de que a Linguística está presente em nossas práticas diárias. Esta presença ocorre tanto quando pensamos nossos planos de trabalho, quanto quando preparamos nossas aulas, ou ainda durante a aplicação de nossos programas de aprendizagem, e, particularmente, quando explicitamos nossas ações em relação ao nosso objeto de estudo e de ensino: a língua. 
Nesta seção, ao manter o foco sobre o campo da LA e da educação/ formação de professores de língua inglesa, quero também abordar as questôes mais afetas aos problemas relacionados à aprendizagem para a docência de línguas, na qual a linguagem tem papel fulcral. Nesse sentido, este texto foi escrito com dois grupos de leitores em mente: os professores formadores de futuros colegas do ensino de língua inglesa, colegas de área de atuação; e os acadêmicos dos cursos de Letras-Inglês, também sujeitos com os quais muitas conquistas profissionais são partilhadas.

Com o primeiro grupo, quero compartilhar o resultado da breve investigação que conduzi com colegas $^{1}$ envolvidos na aprendizagem e/ou no ensino de inglês em diferentes contextos sobre o tema Educational Linguistics, ou, em português, Linguística Educacional. Com o segundo grupo, minha intenção é de chamamento. Espero, sinceramente, que em alguns anos possamos reeditar este estudo e alcançar resultados que deem conta de açôes significativas no que diz respeito à aprendizagem crítica de línguas e de um ensino para a docência comprometido com temas (que considero) essenciais para nossas práticas, como é o caso da explicitação de concepçōes e de definiçõoes relacionadas à LA e às suas subáreas.

Ao abordar a Linguística Educacional - como subárea da LA - e o campo da educação/formação de professores de língua inglesa, este estudo retoma, de certa forma, os primeiros tempos da LA, quando o entendimento vigente era de que o objetivo da área era aplicar teorias linguísticas ao ensino de línguas, estrangeiras em particular (MOITA LOPES, 2006). Na perspectiva deste estudo, essa tendência reducionista não se aplica, na medida em que há a consciência de que os rumos da LA contemporânea contemplam um arcabouço teórico interdisciplinar e que, além disso, o espaço para a pesquisa no âmbito da Linguística Educacional é legítimo, contanto que se vislumbre uma aprendizagem para a docência que outorgue ao professor aprendiz uma educação linguística que possa ser transposta para a sala de aula. Como consequência tangível de uma formação docente dessa ordem, pode-

\footnotetext{
${ }^{1}$ Mais do que compartilhar, quero agradecer a disponibilidade dos colegas que colaboraram com o presente estudo, endereçando a eles a proposição de Cox e Assis-Peterson (2008, p. 51), de constituirmos "uma comunidade formadora por meio do compartilhamento de experiências" que ambicione pela promoção de uma formação docente que seja fruto da evolução daquilo que experimentamos em nossa própria formação e que, agora, podemos intervir através da nossa prática e com a nossa experiência.
} 
se idealizar um ensino de línguas que dê condições para que os alunos da escola básica venham a fazer uso da linguagem como forma de percepção dos seus limites e das suas possibilidades no que tange aos seus recursos linguísticos (SCHLATTER; GARCEZ, 2012).

\section{A linguística educacional}

Os episódios políticos e econômicos que tocaram o mundo por volta da década de 1960 em diante promoveram mudanças pós-colonialistas e incentivaram a intensificação da mobilidade internacional, que já iniciara nos períodos entre guerras e pós-guerra, para culminarem na globalização, fenômeno mundial que acabou por contemplar o inglês como língua comum, capaz de estabelecer a comunicação entre os seus mais diversos usuários (GRADDOL, 2006; LONGARAY, 2009). A partir deste momento, o ensino e a aprendizagem de línguas (notadamente do inglês) foram intensificados por motivações tão diversas quanto controversas (ASSIS-PETERSON e COX, 2007).

Das tendências investigativas da época, e influenciadas pelas pesquisas educacionais que proliferaram a partir da década de 1960, os pesquisadores da área da LA passaram a lançar seus olhares sobre estudos que acolhessem as relações de aprendizagem e de ensino de línguas. Nesse cenário, e devido ao fato de a LA ocupar-se também de outros temas relacionados, Bernard Spolsky (1974b) propôs um campo investigativo mais especificamente relacionado à área da educação. Para o autor,

dentro da linguística aplicada há um subgrupo que merece ser reconhecido como uma unidade lógica. Esse conjunto de atividades, para o qual eu proponho o título "linguística educacional", forma um campo coerente e unificado. O escopo da linguística educacional é a interação da educação formal com a língua. Esse escopo está comprometido em descrever e em analisar a educação linguística em todos os seus aspectos. Esse compromisso envolve a avaliação da competência comunicativa de uma criança quando da sua entrada na vida escolar, nos estágios subsequentes da sua educação, e em todas as demais atividades relacionadas ao sistema educacional que promovam mudanças nos repertórios linguísticos dos alunos. Essas mudanças podem estar relacionadas ao enriquecimento, à supressão, à alteraçâao do uso, ou à adição de um ou mais estilos, variedades ou línguas. (SPOLSKY, 1974b, p. 2. Tradução minha.)

Esse 'campo coerente e unificado' apresentado por Bernard Spolsky foi aprimorado e suas questôes centrais têm merecido a atenção dos pesquisadores 
de áreas quase tão abrangentes quanto aquela que a originou. Dos campos que se inter-relacionam como subáreas da LA, a Linguística Educacional também acolhe os conhecimentos provenientes da sociolinguística, da psicolinguística, da antropologia, da neurolinguística, além das políticas educacionais (LO BIANCO, 2008; MASSINI-CAGLIARI, 2004; SPOLSKY, 2005) e temas como ideologias, condições sociopolíticas, sistemas de crenças que determinam atitudes em relação às línguas (para o aprofundamento destas questôes e de outras relacionadas, ver McGroarty, 2008, p. 98-112). Tópicos que compóem os contextos estudados e suas respectivas manifestações culturais, juntamente com os temas relativos às práticas bilíngues, às línguas indígenas e aos portadores de necessidades especiais, por exemplo, também compõem o escopo temático da Linguística Educacional (BLOCK, 2004; McKINNEY e NORTON, 2008; SHIN e KUBOTA, 2008; SUPALLA e CRIPPS, 2008). Enfim, a partir do cenário acima fica possível compreender a definição compartilhada por Hult (2008 apud HORNBERGER, 2001):

Linguística educacional é uma área de estudos que integra as ferramentas de pesquisa da linguística e outras disciplinas relacionadas das ciências com vistas à investigação holística da ampla gama de tópicos relacionados à língua e à educação. Como área investigativa a linguística educacional é jovem. (...) A história da linguística educacional é inextricavelmente ligada à linguística aplicada, com a qual ainda mantém uma relação simbiótica. (HULT, 2008, p. 10. Tradução minha.)

Seguindo a proposta de Spolsky (1974b), a Linguística Educacional tem merecido a atenção de pesquisadores e de programas de ensino em níveis universitários. Em termos mais abrangentes, muitos países têm dedicado atenção à Linguística Educacional através de políticas específicas de capacitação de professores e de gestão educacional pública. Essa atenção, devida especialmente aos aspectos econômicos, políticos e culturais decorrentes da globalização, tem constituído um cenário próprio dentro do campo do ensino de línguas, em especial do inglês. Assim, e em função da expansão da língua inglesa nos contextos globais mais diversos, tópicos como as diferentes variações do inglês ao redor do mundo, o crescimento do número de profissionais não nativos atuando no ensino de inglês, a ampliação do conhecimento local no ensino da língua, as pedagogias pós-método, as políticas educacionais de ensino de línguas e a adoção das línguas locais como meio de instrução, para citar alguns, têm contribuído para o debate crítico embasado nos princípios da Linguística Educacional (BALDAUF Jr., LI, ZHAO, 2008; 
CRYSTAL, 1997 e 2002; GRADDOL, 2006; LO BIANCO, 2008; MASSINI-CAGLIARI, 2004; RAJAGOPALAN, 2004; SHIN e KUBOTA, 2008; SPOLSKY, 2005).

Dos tópicos mencionados, é relevante a retomada destes temas devido à relação dos contextos de atuação dos leitores para quem este texto se destina - nomeadamente, os futuros professores de línguas e os professores formadores -, dado o caráter multiplicador da docência. Além disso, entendemos que é através da intervenção informada dos docentes - formados e em formação que os tópicos relacionados à Linguística Educacional podem contribuir significativamente para iniciativas de gestores escolares e, idealmente, refletir em ações públicas relacionadas à educação linguística dos cidadãos em geral.

Como ponto de partida, é importante que seja retomada a sugestão de Spolsky (1974) quanto ao papel do cientista das línguas humanas no âmbito escolar. Originalmente, o estudioso propóe que, "a tarefa primordial do linguista educacional [seja] oferecer informaçôes relevantes à formação de políticas linguístico-educacionais bem como a sua implementação" (SPOLSKY, 1974, p. 554). Seguindo essa linha de raciocínio, Faraco (2007) assevera que a questão da língua no Brasil extrapola a linguística porque se trata de "uma questão que interessa à polis como um todo, na medida em que ela atravessa diretamente e afeta profundamente inúmeras situações sociais" (FARACO, 2007, p. 39). Nesse sentido, Hult (2008) adverte que o foco na formação de políticas linguístico-educacionais dá-se, portanto, tanto de forma indireta quanto direta. Indiretamente, pode-se considerar que o conhecimento gerado por especialistas interessados nas questóes da Linguística Educacional, quando aplicado no processo de elaboração de políticas de ensino, pode influenciar a prática educativa como um todo na medida em que açóes desta ordem estão relacionadas ao desenvolvimento cultural de um povo. Por outro lado, esse conhecimento pode orientar práticas educativas sólidas, porque fundamentadas e direcionadas a contextos sociais e culturais específicos.

As práticas educativas normalmente são afetadas por políticas linguísticas que se manifestam em vários contextos dentre os quais podemos arrolar desde os lares de famílias envolvidas direta ou indiretamente no ensino de línguas às suas crianças até as aulas de língua materna, aulas de línguas adicionais, ${ }^{2}$ aulas de

\footnotetext{
${ }^{2} \mathrm{O}$ termo línguas adicionais é opção alternativa a linguas estrangeiras como matéria escolar; a terminologia é explicada pormenorizadamente na seção A EDUCAÇÃO LINGUÍSTICA, no presente texto.
} 
segunda língua, entre outros (VAN LIER, 2008, p. 596). Em qualquer desses contextos, é importante que tenhamos em mente o papel destas políticas e os seus respectivos âmbitos.

Spolsky (2005, p. 2155) sugere níveis dentro dos quais os sujeitos são mais ou menos afetados, dependendo da importância que é dada à educação linguística propriamente dita. O primeiro deles é o âmbito familiar, considerando tanto as famílias de composição monolíngue quanto as famílias onde há a presença de mais de uma língua envolvida. No primeiro caso, a prática linguística pode ser manifesta através da sanção de itens indesejados (como palavrōes), pelo reforço de estilo específico ("Diga 'por favor'?"), ou ainda por correçōes gramaticais pontuais ("Não é para 'mim' fazer; é para 'eu' fazer."). No caso das famílias onde há mais de uma língua envolvida, os aspectos relacionados são obviamente mais complexos, dependendo da situação que gerou a família, ou seja, se por motivações migratórias, se por questōes políticas ou culturais, por exemplo. Ao extrapolar o meio familiar, outro nível apontado por Spolsky é formado por âmbitos de socialização intermediária, como a frequência à igreja ou ao clube, ou à interação com o comércio e espaços similares.

Além dos âmbitos familiares e de socialização intermediária, Spolsky (2005) aponta o contexto escolar como o mais importante no que tange às políticas linguísticas, uma vez que este é o primeiro espaço de socialização efetiva do indivíduo. Um exemplo claro citado pelo autor diz respeito à língua de instrução nas escolas.

De uma perspectiva mais abrangente, os contextos escolares, por sua vez, estão sujeitos às políticas educacionais de cada país que, soberanamente, define ou sugere as abordagens e as práticas a serem contempladas. Como os sistemas educacionais são propriedades dos Estados (LO BIANCO, 2008), aspectos relacionados à educação linguística ficam, de certa forma, sujeitos às prioridades estabelecidas pelos governos. Assim, pode-se dizer que no âmbito da educação linguística os sistemas educacionais são pautados pela combinação de políticas e de questôes relacionadas à Linguística Educacional. Através destas combinaçôes, as instâncias formais de instrução ficam, em última análise, encarregadas da organização dos conhecimentos históricos, científicos, culturais, matemáticos, e, entre outros, da herança instrucional que perpassa o conhecimento da/s língua/s e sobre a/s língua/s, inclusive do conhecimento metalinguístico, produzido pelos linguistas.

Dos tópicos que podem ser contemplados pela Linguística Educacional, os mencionados nos parágrafos anteriores não esgotam a área de abrangência 
deste ramo da LA. Pelo contrário, as relações políticas, culturais e econômicas estão inexoravelmente imbricadas com as línguas e com as questões de poder e de transformação das sociedades, especialmente em tempos de globalização (SHIN e KUBOTA, 2008; ASSIS-PETERSON e COX, 2007). Neste sentido, é coerente admitir que a expertise que pode (e deve!) ser compartilhada nos meios universitários leve aos acadêmicos uma educação linguística necessária para a formação dos futuros professores de línguas. Estes, por sua vez, desafiarão os seus alunos nos âmbitos de ensino fundamental e médio a conhecer o outro e a si mesmo através do conhecimento das diferenças e das semelhanças provenientes de uma educação linguística que valorize a diversidade a partir da sala de aula e da própria realidade.

\section{A educação linguística}

Das concepções de educação linguística, e para os fins para os quais este texto se destina, talvez a mais abrangente e objetiva até o momento seja aquela proposta por Marcos Bagno e Egon Rangel. Para os autores, educação linguística é

o conjunto de fatores socioculturais que, durante toda a existência de um indivíduo, lhe possibilitam adquirir, desenvolver e ampliar o conhecimento de/sobre outras línguas, sobre a linguagem de um modo mais geral e sobre todos os demais sistemas semióticos. Desses saberes, evidentemente, também fazem parte as crenças, superstições, representações, mitos e preconceitos que circulam na sociedade em torno da língua/linguagem e que compõem o que se poderia chamar de imaginário linguístico ou, sob outra ótica, de ideologia linguística. Inclui-se também na educação linguística o aprendizado das normas de comportamento linguístico que regem a vida dos diversos grupos sociais, cada vez mais amplos e variados, em que o indivíduo vai ser chamado a se inserir. (BAGNO e RANGEL, 2005, p. 63)

Considerando que "o escopo da Linguística Educacional é a interação da educação formal com a língua" (SPOLSKY, 1974b, p. 2) e que os sistemas educacionais estão sob o jugo dos Estados (LO BIANCO, 2008, p. 113), é coerente o entendimento de que a aquisição, o desenvolvimento e a ampliação do conhecimento de/sobre os usos das línguas, entre outros, sejam atributos da escola. A criança, ao alcançar idade escolar e ao ingressar nesta instituição social, inicia a sua inserção no mundo das mais diversas e inusitadas 
manifestaçōes linguísticas. A partir daí, a importância que tal socialização adquire poderá ser fundamental para a aceitação ou para o repúdio das manifestações que compõem a ideologia linguística que o sujeito desenvolverá. Essas manifestações estarão, portanto, relacionadas à sua língua materna e à/s sua/s língua/s de socialização intermediária. Nesse sentido, quanto mais receptivo ou exposto às manifestações linguísticas do seu entorno, maior será o proveito do sujeito, que terá como perceber a si mesmo e ao outro.

Para ilustrar o quanto a questão da diversidade linguística pode impactar no entendimento do sujeito e da própria cidadania, recorremos a MassiniCagliari (2004) que, em uma análise da situação linguística no Brasil, aponta para a relação entre a língua portuguesa e as mais de 200 outras faladas no país. Para a autora, as iniciativas que deram ao português o status de língua oficial brasileira estão, de certa forma, vinculados a um processo histórico de unificação linguística que ignora, reprime, penaliza, discrimina, neutraliza ou nega (dependendo do contexto e do momento histórico) uma realidade multilíngue evidente na sociedade brasileira, inclusive em nossas salas de aula, ainda hoje. Para exemplificar, as línguas dos imigrantes que povoaram os diferentes cantos brasileiros (ajudando, inclusive, o país a prosperar social, cultural e economicamente), as mais de 170 línguas indígenas ainda hoje faladas no Brasil e as diferentes variaçóes da própria língua portuguesa ainda são, sob vários aspectos, desrespeitadas como manifestações legítimas dos cidadãos brasileiros. Essa deficiência nacional em lidar com a diversidade linguística da vasta maioria da população acaba por legitimar o preconceito dentro da nossa sociedade, impedindo a promoção da educação e da diversidade como um ativo social, uma vez que priva os seus cidadãos da alteridade cultural e, portanto, de manifestaçóes genuinamente brasileiras. Ao desconhecer o outro como influência legítima desconhece-se também a si mesmo porque a falta de referência externa fortalece a miopia que distancia o cidadão da sua inserção no mundo do trabalho, das tecnologias, das ciências, da heterogeneidade e da complexidade que é, em última análise, o mundo em que estamos inseridos neste momento histórico.

Da circunscrição acima, é importante que se saliente que há mais de quatro décadas a produção de conhecimento na área da linguística vem sendo aprimorada e compartilhada (FARACO, 2007), inclusive, no âmbito de outras línguas, como o inglês (RAJAGOPALAN, 2006). Linguistas brasileiros, atentos às questões metodológicas relacionadas ao ensino de inglês não só colaboraram com a introdução de abordagens desenvolvidas no exterior, como 
também contribuíram com propostas mais direcionadas às necessidades nacionais (GOMES DE MATOS e PINTO, 2000; COX e ASSISPETERSON, 1999; BARBARA e SCOTT, 1994; CAVALCANTI, 1986; HOLMES, 1989; CELANI et al., 1988; GOMES DE MATOS, 1968, 1970, 1976 apud RAJAGOPALAN, 2006).

Dessa perspectiva, e retomando questões relacionadas às políticas educacionais, a Lei de Diretrizes e Bases da Educação (BRASIL, 1996) introduziu mudanças substanciais às políticas de ensino de línguas nos níveis de ensino fundamental e médio. Um dos grandes méritos da Lei foi a descentralização das decisões educacionais, transferindo essa tarefa para as autoridades estaduais e municipais. Apesar de a descentralização ter sido bem recebida pelas autoridades escolares, estes âmbitos educacionais foram imbuídos de responsabilidades que não estavam preparados para assumir (BOHN, 2003, 106 apud RAJAGOPALAN, 2006). Além disso, e apesar de não mencionar o ensino de línguas no nível superior, o inglês e as outras línguas foram contemplados em documentos orientadores, como os Parâmetros Curriculares Nacionais: Língua Estrangeira (BRASIL, 1999), os PCN+ (BRASIL, 2002) e, mais recentemente, as Orientações Curriculares para o Ensino Médio: conhecimentos de línguas estrangeiras (BRASIL, 2006).

A partir da Lei e das orientações, coube aos estados a incumbência de desenvolver suas próprias orientaçôes. No Estado do Rio Grande do Sul, equipes de professores foram designadas a pesquisar, a desenvolver, a escrever e a propor aplicaçôes práticas dos Referenciais Curriculares estaduais (RIO GRANDE DO SUL, 2009) que compõem as áreas do conhecimento contempladas pelas orientações nacionais, a saber: Linguagens Códigos e suas Tecnologias: Língua Portuguesa, Literatura, Língua Estrangeira Moderna (Inglês e Espanhol) e Educação Física e Arte; Matemática e suas Tecnologias; Ciências da Natureza e suas Tecnologias: Biologia, Física e Química; e Ciências Humanas e suas Tecnologias: História, Geografia, Sociologia e Filosofia.

Distribuídos em cinco volumes, ao primeiro coube orientar sobre as disciplinas de Língua Portuguesa, Literatura e Língua Estrangeira Moderna (Inglês e Espanhol). ${ }^{3} \mathrm{O}$ grande mérito deste volume se deve, justamente, à proposta de integração das disciplinas contempladas de uma perspectiva da

\footnotetext{
${ }^{3}$ Os autores deste volume são Ana Maria Ribeiro Filipouski e Diana Maria Marques (Língua Portuguesa e Literatura); Luciene Juliano Simões (Língua Portuguesa); e Margarete Schlatter e Pedro de Moraes Garcez (Língua Estrangeira Moderna).
} 
educação linguística. Além disso, todas as áreas apresentam situações-modelo de aplicação prática dos respectivos anos de progressão curricular dos alunos do ensino fundamental ao médio $\left(6^{\circ}\right.$ ao $9^{\circ}$ ano do ensino fundamental e $1^{\circ}$ ao $3^{\circ}$ ano do ensino médio), com orientações específicas para os professores, contemplando os aspectos teórico-práticos envolvidos e informando ao docente das especificidades da proposta, aula a aula. ${ }^{4}$

Apesar de terem sido desenvolvidos para a aplicação na rede pública de ensino, os Referenciais Curriculares-RS (a partir daqui, Referenciais) compõem um quadro teórico e de sugestôes práticas que pode abranger toda a rede de ensino regular, tanto pública quanto particular, contribuindo com noções, conceitos, propostas, aplicaçōes e sugestōes que deveriam ser compartilhadas, inclusive, com a comunidade escolar em geral: pais, coordenadores pedagógicos, diretores de escolas, por exemplo. Do ponto de vista da educação linguística, as orientações da Secretaria da Educação-RS aos professores da rede estadual do ensino estão fundamentadas na proposição de projetos que contemplam os conteúdos relacionados a eixos temáticos que se sustentam por gêneros do discurso, com vistas ao desenvolvimento de competências e de habilidades para ler e escrever em línguas adicionais.

'Línguas adicionais' é a nomenclatura utilizada pelos autores dos Referenciais para tratar o objeto de ensino do componente curricular "Língua Estrangeira”. A escolha é justificada por aspectos contemporâneos, como a adição de outra língua ao repertório linguístico que o aluno já traz de níveis anteriores (como do âmbito familiar) ao ingressar na educação formal. Judd et al. (2003) também preferem o termo 'adicional' aos mais comumente utilizados, como segunda língua ou língua estrangeira, e justificam. Para os autores, o sentido de adicional pode ser aplicado a quaisquer outras línguas que o aluno queira aprender, exceto, obviamente, à sua língua materna (ou primeira língua). Além disso, 'estrangeiro' pode sugerir estranheza, exotismo, distanciamento - conotações indesejáveis (p. 6) e opostas ao sentido de ampliação de horizontes e de possibilidades de comunicação a fim de interagirem com falantes nativos e não nativos da língua em questão. Os autores dos Referenciais contextualizam e justificam a escolha pelo termo 'adicional' em relação às línguas espanhola e inglesa por considerarem que

\footnotetext{
${ }^{4}$ Todo o material está disponibilizado no site da Secretaria da Educação do RS e pode ser acessado através do endereço <http://www.educacao.rs.gov.br/pse/html/ refer_curric.jsp?ACAO=acaol> (acesso em $1^{\circ}$ de outubro de 2012).
} 
as duas línguas adicionais oferecidas nas escolas da rede pública estadual, são de fato as duas principais línguas de comunicação transnacional, o que significa que muitas vezes estão a serviço da interlocução entre pessoas de diversas formaçôes socioculturais e nacionalidades, de modo que é comum não ser possível identificar claramente nativos e estrangeiros. De fato, se consideramos que o espanhol e o inglês constituem patrimônios relevantes para a formação do cidadão a ponto de nos ocuparmos do seu cultivo na educação nacional, entendemos que, de alguma maneira, essas línguas fazem parte dos recursos necessários para a cidadania contemporânea. Nesse sentido, são línguas adicionais, úteis e necessárias entre nós, não necessariamente estrangeiras. Assim, falar de uma língua adicional em vez de língua estrangeira enfatiza o convite para que os educandos (e os educadores) usem essas formas de expressão para participar na sua própria sociedade. (RIO GRANDE DO SUL, 2009, p. 127-128)

Outro aspecto que deve ser levado em consideração quanto ao sentido prático que a educação linguística pode promover está relacionado ao papel do professor na proposta do ensino de uma ou mais línguas adicionais no âmbito escolar. Historicamente, e devido a crenças já profundamente enraizadas no imaginário coletivo, é voz corrente que a aprendizagem de línguas não é bem sucedida na escola regular. Ocorre que o senso comum, determinado pelo mau trato à educação nacional e à proliferação dos cursos de idiomas, "autorizou" a escola a desacreditar os professores de línguas. O senso comum, ainda nesse sentido, aparentemente expandiu-se de tal maneira que atingiu, inclusive, os próprios docentes que, desacreditados, desacreditaram-se de ensinar o que seus alunos não aprenderiam mesmo, e cederam à realidade apresentada. Essa realidade, por sua vez, abriu as portas aos pais, gestores do âmbito familiar (SPOLSKY, 2005), que, determinados a proporcionar o melhor aos seus filhos, afastaram-nos da aprendizagem de inglês na escola (...já que seus filhos não aprenderiam a língua naquele contexto mesmo). Não demorou muito para que toda a sociedade (mais especificamente quem pudesse custear) se orgulhasse de frequentar os cursos de idiomas e não acreditasse na aprendizagem de inglês na escola regular, ignorando o papel de cada uma dessas instâncias na promoção da aprendizagem de línguas.

Ora, as questões educacionais envolvidas neste cenário estão equivocadamente constituídas na medida em que as expectativas do ensino de línguas adicionais na escola são colocadas muito além do possível e do imaginável por qualquer profissional da educação que já tenha, ele próprio, se dedicado à aprendizagem de outra/s língua/s. Garcez (2008d) descreve o quadro 
possível para esse contexto ao afirmar que o objetivo da escola regular de tornar os alunos falantes ou proficientes ao final da educação básica deve ser colocado em segundo plano. Ainda que possa ser frustrante para muitos, o linguista assevera que o propósito do ensino de línguas adicionais na escola deve ser a expansão das possibilidades de encontro do aluno consigo mesmo através do outro, da língua do outro. Ao se conhecer melhor, o aluno terá condições de se ver "diante dos limites de sua atuação e poderá contemplar novos horizontes de atuação, examinar seus recursos e procurar ampliá-los" enquanto que os professores, por sua vez, poderão "enxergar a si mesmos no mundo e dispor de mais elementos para conhecer as suas próprias realidades locais" e, assim, promover nos aprendizes a reflexão proposta pelo autor através dos questionamentos: "quem sou eu nesse mundo? Quais são os limites do meu mundo? Quais são as minhas comunidades de atuação? Onde está essa língua? De quem é essa língua? Para que serve essa língua? O que é que essa língua tem a ver comigo?" (GARCEZ, 2008d, p. 52).

De acordo com o que lemos até aqui, o cenário da Linguística Educacional, que acolhe a educação linguística, é bastante amplo e teve suas origens em momentos históricos que demandaram por mudanças e por quebra de paradigmas que estavam, de certa forma, imbricados em áreas científicas afins. A clareza de alguns e a receptividade de outros, somadas à identificação das necessidades prementes de uma maioria foi o que, aparentemente, colaborou para a constituição desta área investigativa e para a sua consequente expansão. Se tomarmos este raciocínio em relação ao ensino de língua inglesa na escola regular de hoje em dia, lamentavelmente ainda teremos praticamente o mesmo cenário apresentado por Rodrigues há quase meio século:

$\mathrm{O}$ ensino de línguas estrangeiras no Brasil apresenta grandes deficiências sobretudo de duas naturezas: por um lado, deficiências técnicas, metodológicas, devidas ao generalizado desconhecimento da moderna pedagogia, baseada no conhecimento científico das estruturas linguísticas; por outro lado, a falta de oportunidades para a aprendizagem de grande quantidade de línguas importantes para o desenvolvimento cultural e econômico do país. (RODRIGUES, $1966,12)$ 
Mesmo assim, e porque os cenários mudam e os paradigmas são quebrados, a ciência evolui - a clareza de alguns e a receptividade de outros permanecem e se ampliam de acordo com as novas demandas sociais e contextuais. Deste modo, e apesar de o cenário descrito por Rodrigues (1966) ainda ser reconhecido por muitos dos leitores deste texto, persiste a demanda por investigaçōes. Assim, partimos do senso comum, das perguntas de Garcez (2008d), dos Referenciais (RIO GRANDE DO SUL, 2009) fundamentados nas determinações legais (BRASIL, 1996) e dos resultados de estudos dos cientistas das línguas humanas para manter a curiosidade investigativa e para conduzir o breve estudo apresentado a seguir.

\section{O estudo}

\section{Os participantes}

Quarenta participantes foram inicialmente selecionados de minha lista pessoal de endereços eletrônicos. Apesar de todos serem colegas ou ex-alunos, as respostas ficaram anônimas, uma vez que os colaboradores não eram identificados quando da análise devido à formatação inicial do questionário e do relatório, previamente elaborados com esta característica. Os critérios de seleção dos colaboradores observaram os seguintes itens, não excludentes: todos deveriam ser graduados em língua inglesa, com experiência ou com formação no ensino da língua, ou que fossem docentes da área de línguas com pósgraduação (mestres ou doutores). Todos os participantes receberam e-mails nominais em inglês, conforme apresentado na Figura 1. Dos quarenta contatos feitos, 28 retornaram os questionários, totalizando $70 \%$ de participação. 


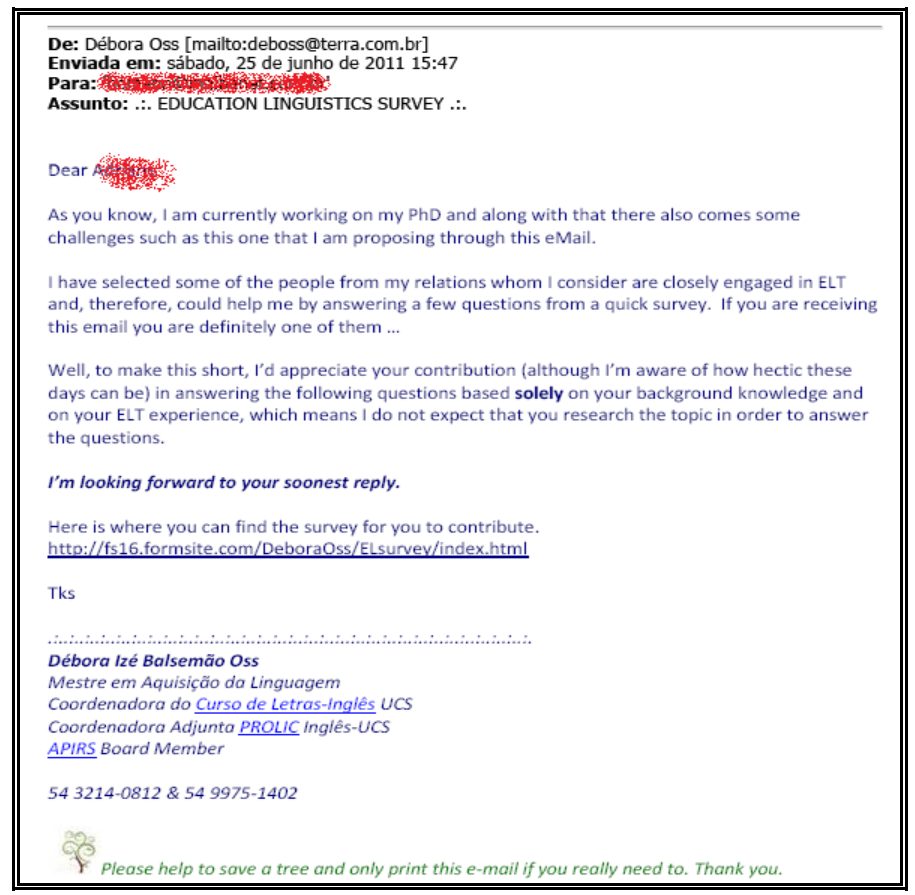

FIGURA 1 - E-mail enviado aos respondentes em potencial.

\section{A geração dos dados}

Com a finalidade de vislumbrar um quadro constituinte do panorama relativo à afinidade dos professores de inglês sobre o tema Linguística Educacional, foi elaborado um questionário composto de oito questôes de múltipla escolha solicitando aos colaboradores que respondessem às perguntas baseados somente em seu conhecimento prévio sobre o tema, tanto em relação à sua aprendizagem (ou seja, a formação do colaborador) quanto em suas experiências no ensino de inglês (quando/se fosse o caso). Nas instruções do questionário foi esclarecido que não era esperado dos colaboradores que as suas respostas fossem baseadas em pesquisas. O questionário foi proposto aos participantes em língua inglesa, uma vez que foi concebido para ser aplicado a colaboradores que tivessem domínio da língua, considerando a sua formação prévia.

Através das perguntas era esperado que os respondentes sinalizassem o seu conhecimento e a sua familiaridade exclusivamente quanto ao tema Linguística Educacional. Sendo assim, não foram oferecidas referências ou 
pistas acerca das relaçõoes entre LA, educação linguística e o tema em questão, corroborando a solicitação explícita aos respondentes, de que não buscassem informações que subsidiassem as suas respostas.

\section{Educational Linguistics a survey means I do not expect that you research the topic in order to answer the questions. is NO to this question, jump to \#4) \\ $\square$ Yes \\ No \\ (2) When did you first hear about it? \\ $\square$ I have always known about it. \\ $\square$ I have just learned about it. \\ $\square$ I have been reading about it since I was at school. \\ $\square$ I studied it deeply when I was at school. \\ $\square$ Educational Linguistics has been a part of my teaching ever since}

Answer the following questions based SOLELY on your background knowledge and on your ELT experience, which

* (1) Are you acquainted with the area of study called Educational Linguistics? (if your answer

(3) How much emphasis on Educational Linguistics did ELT education program/s that you have been through address?

$\square$ We were just introduced to its main concepts.

$\square$ We were assigned some readings and we actually approached and discussed some of its main concepts.

$\square$ We were requested to present seminars on its main concepts.

$\square$ We actually conveyed some research about its main concepts.

Other

* (4) Where did you take most of your ELT education?

In Brazil.

Abroad.

$\square$ Please inform the country:

* (5) How long have you been involved in ELT?

$\square$ Please specify

* (6) What is your main working context?

$\square$ Private sector

$\square$ Public sector

$\square$ Language institutes

$\square$ One-to-one classes

$\square$ Other (please specify)

* (7) What is your students' main age range?

$\square$ Teenagers (from about 13-18).

$\square$ Adults and young adults in their $20 \mathrm{~s}$.

$\square$ Golden agers (adults in ther 50 s on).

$\square$ Kids.

$\square$ Other (please specify)

* (8) Which ELT aspects do you consider of main importance in your teaching? ～(you may inform more than one item)

$\square$ Language, e.g., structural aspects of it.

$\square$ Use and usage, e.g., everyday chunks of language.

$\square$ Affective factors related, e.g., orientations for learning.

$\square$ Literature, e.g., literary and cultural references.

$\square$ Instrumental, e.g., specific aspects of the language.

$\square$ Other (please specify)

Please leave any extra comments/information that you wish to make regarding Educational Linguistics.

Thank you for your contribution!

FIGURA 2 - Versão para impressão do formulário proposto online 
Para tornar o processo mais ágil para os participantes, o questionário foi proposto virtualmente, através do link fornecido no contato feito via correio eletrônico aos colaboradores previamente selecionados. Os dados foram gerados através das respostas dos participantes e armazenados no website através do qual o questionário foi elaborado e para onde as respostas eram encaminhadas imediatamente após o respondente acionar "submit". Os relatórios eram armazenados a cada dez questionários respondidos e enviados; logo após o recebimento dos grupos de questionários, os relatórios eram exportados do programa original no formato planilha de dados para fins de análise. A análise quantitativa foi feita a partir da contagem simples das respostas, sem que qualquer tratamento estatístico tenha sido aplicado. Esta opção se deu devido ao caráter informativo do levantamento, uma vez que a amostra era reduzida e não tinha pretensões de generalizar conclusões a partir dos resultados obtidos.

\section{As questões propostas}

Como podem ser observadas na Figura 2, as questões eram de caráter bastante geral, sem contemplar nenhum item específico da Linguística Educacional. O que se quis averiguar através das questôes propostas foi se o conceito de Linguística Educacional fez parte da formação dos professores participantes tanto nos níveis de graduação quanto de pós-graduação e quais as relações os respondentes tinham condições de estabelecer, com base em seu conhecimento prévio apenas. Além disso, também foi considerado que a partir do entrecruzamento dos resultados das análises poder-se-ia lançar luzes sobre as possibilidades pedagógicas que contemplam os achados da academia nas práticas dos professores formadores e dos acadêmicos de Letras, compartilhando, assim, a responsabilidade da inserção da Linguística Educacional nas aulas de línguas das escolas de ensino regular. Finalmente, como a última questão era aberta, aos participantes foi disponibilizado espaço para comentar ou informar ou simplesmente deixar alguma contribuição sobre qualquer aspecto que lhes parecesse relevante com relação ao tema Linguística Educacional; tais contribuições são utilizadas ao longo desta seção como forma de contemplar as respostas e também de elucidar ou de corroborar algumas das questôes que deram origem ao presente estudo. 


\section{As respostas obtidas}

A partir das respostas ao questionário foi possível saber um pouco mais sobre o perfil dos participantes. Dos respondentes, $89 \%$ tiveram sua formação em ensino de língua inglesa (doravante ELT) exclusivamente no Brasil. Destes, pouco mais da metade (53\%) fazia parte do grupo que informou não estar familiarizado com a área da LA denominada Linguística Educacional. Além destes, somente 8\% desenvolveram algum tipo de pesquisa sobre o tema, 16\% leram e discutiram alguns dos conceitos inerentes à área e outros $12 \%$ foram apresentados aos conceitos. Do total dos respondentes, foi possível inferir que a maioria (65\%) não recebeu informação aprofundada sobre o tema nos programas de ELT de que participou, como pode ser observado pelas contribuiçôes à pergunta aberta no final do questionário (respondida por $25 \%$ do total dos colaboradores): - "It has always depended much on the individual teacher not on programs."

As asserções acima autorizam a inferência de que o tema não foi abordado de forma aprofundada nos programas de formação docente da maioria dos respondentes, e que, além disso, quando indagados, mesmo demonstrando condições de intuir sobre o que o tema trataria, falta-lhes a condição de apropriação conceptual, como é possível depreender a partir de outra das respostas à pergunta aberta - "It is possibly an area of study that proposes a connection between Linguistics and other disciplines related to education".

A partir das contribuiçóes apresentadas e da maneira como entendemos a educação linguística dos professores de línguas, queremos propor que o tema Linguística Educacional seja tratado explicitamente nos programas de formação inicial dos alunos de Letras-Inglês - e, quiçá, de outras línguas também, inclusive a portuguesa. Nesse sentido, as questóes que envolveriam leituras, reflexões, ensaios e relatos investigativos seriam parte da formação inicial dos futuros docentes, em oposição à inserção do tema nos níveis de pós-graduação somente, como fica evidenciado na asserção de outro colaborador: - "The first time I read about the subject was in a class about Language Policy and was one discipline I took at the doctorate course." Em se fazendo isso, entendemos, como Cavalcanti (1986), que os futuros professores - e os professores formadores igualmente - teriam condições de pontuar de forma mais apropriada as questôes relacionadas ao uso da linguagem - foco da LA - tanto dentro quanto fora do contexto escolar, ou seja, na "interação face-a-face (conversação) ou ouvido-a-ouvido (conversação telefônica) e a interação a distância mediada pelo texto. Estes dois tipos de interação em sua abrangência incluem o ensino de línguas" (CAVALCANTI, 1986, p. 8). 
Decorrente deste posicionamento de Marilda C. Cavalcanti, ao qual me alio, poderíamos - nós, professores formadores - estabelecer relaçōes mais transparentes entre o objeto de ensino e a teoria que o ampara. Uma alternativa seria enfatizar a atenção no entendimento e na reflexão acerca dos conceitos relacionados à área da LA com vistas à redução de equívocos como a contribuição de um dos respondentes sugere: "I have been familiar with the concept of language education, which I have been applying to my teaching for over 15 years. Somehow, when you promote education through language you probably need to apply notions drawn from linguistics, i.e. linguistics applied to language education".

Desta asserção, dois aspectos são de especial interesse na análise das contribuiçōes espontâneas dos colegas colaboradores do estudo. O primeiro diz respeito à incerteza quanto ao tema, demonstrada na utilização dos termos 'possibly' e 'probably' que, ainda que tenham sido utilizados com motivação expressiva, denotam insegurança no trato com o tópico em questão. Reiterando a ênfase ou a instrução explícita de termos e conceitos sugeridos anteriormente, valho-me da sugestão que Bolitho (1998) propõe aos professores quando do ensino de língua inglesa, ou seja, a inclusão de metalinguagem, da língua do aluno e de termos indispensáveis pode ser um recurso muito útil aos professores, especialmente se considerarmos que a terminologia linguística é abordada na escola desde as séries iniciais. Da mesma forma, os professores aprendizes se beneficiariam da instrução explícita, uma vez que "este tipo de conhecimento sobre a língua [que será ensinada] não deve ser descartado como substituto para produzir a língua [alvo] de forma eficiente; [este conhecimento] simplesmente reconhece a dimensão cognitiva que ajuda a maioria dos aprendizes na direção da competência comunicativa" (BOLITHO, 1998, p. 5) - ao que eu acrescentaria "na direção da competência profissional", no caso dos professores formadores e, desejavelmente, dos futuros docentes.

O segundo aspecto detectado a partir das respostas à questão aberta diz respeito aos equívocos conceptuais relacionados à LA. Tais equívocos, notadamente comuns entre os pares, são pontuados na contribuição de Cavalcanti (1986) de há mais de duas décadas e que permanece mal distinto ainda hoje, como pode ser observado não só, mas também através do registro gerado para o presente estudo ("you probably need to apply notions drawn from linguistics, i.e. linguistics applied to language education"). Com relação a esta questão, Marilda Cavalcanti esclareceu que

A LA é abrangente e multidisciplinar em sua preocupação com questóes de uso de linguagem. Ela tem um objeto de estudo, princípios e metodologias próprios, e já começou a desenvolver seus modelos 
teóricos. Dada a sua abrangência e multidisciplinaridade, é importante desfazer os equacionamentos da LA com a aplicação de teorias linguísticas e com o ensino de línguas. No primeiro caso, é necessário salientar que o termo "Linguística Aplicada a ..." é inapropriado uma vez que em LA não se aplica a Linguística (...) A denominação "Linguística Aplicada: Interação Médico-Paciente" ou "Linguística Aplicada: Ensino de Línguas" é mais apropriada ao trabalho desenvolvido em LA, uma vez que chama a atenção sobre o objeto de estudo, (...) [e] a visão de LA deve ser ampliada para que o equacionamento seja, não ao nível do ensino de línguas, mas ao nível de questóes de uso da linguagem na escola ou em um contexto social mais amplo." (CAVALVANTI, 1986, p. 9)

A partir deste levantamento inicial, foi possível verificar que a Linguística Educacional realmente não encontrou espaço para discussão mais aprofundada em relação aos seus conceitos básicos, especificamente no que diz respeito à formação superior dos profissionais da área de Letras que responderam a pesquisa - ver Figura 3. Apesar da motivação inicial deste estudo de certa forma prever tal quadro, a surpresa maior deu-se em decorrência do percentual de respondentes que não tinham familiaridade com o tema, apesar de terem sido convidados a participar do estudo justamente por serem graduados e pósgraduados na área de línguas, como pode ser observado a partir da resposta à pergunta aberta de outro respondente: - "I am acquainted with Applied Linguistics on teaching and I would like to know about Educational Linguistics."
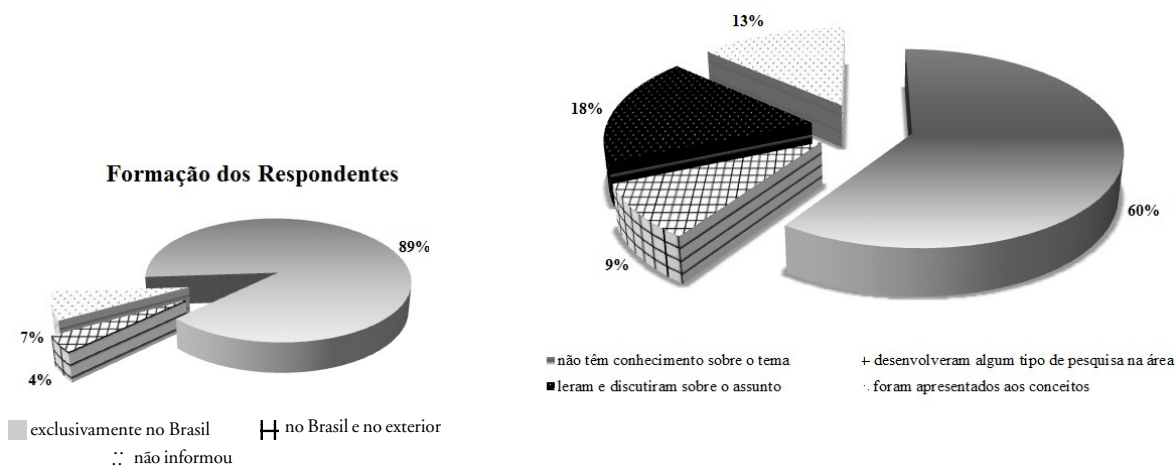

"não têm conhecimento sobre o tema

- leram e discutiram sobre o assunto

+ desenvolveram algum tipo de pesquisa na área for am apresentados aos conceitos

FIGURA 3 - Perfil dos respondentes em relação ao conhecimento sobre o tópico Educação Linguística

Em decorrência dessas constatações, é importante reiterar que o conhecimento gerado a partir desta área investigativa é diretamente aplicável 
através de práticas educativas sólidas (HULT, 2008). Assim, e de acordo com as asserções dos respondentes do estudo, a dependência de iniciativas isoladas é, em verdade, um tanto quanto desalentadora na medida em que pode impactar diretamente no nível de comprometimento do educador que, por mais engajado que seja, dependerá de suas iniciativas individuais para manter a qualidade do seu ensino e o seu envolvimento profissional, como pode ser percebido através da contribuição (quase lamento) de um dos colaboradores: - "I found about it on my own". Neste sentido, permanece o desafio, já que é tarefa da Linguística Educacional "a proposição de ações relevantes para a elaboração de políticas linguístico-educacionais bem como a sua implementação" (HULT, 2008, 20). Em tempo, é importante enfatizar a sugestão de Bagno e Rangel (2005), que propõem como "tarefa mais urgente" a promoção da reflexão e da ação, capazes de articular as políticas públicas de ensino de língua (BAGNO; RANGEL, 2005, p. 68). Os autores, apesar de referirem ao ensino de língua portuguesa, ao mencionarem a educação linguística incluem de certa forma as outras línguas que também são componentes curriculares dos alunos da educação básica, onde ELT se insere.

Apesar de os colaboradores terem, de certa forma, atendido a um chamado da pesquisadora, uma das curiosidades do estudo em relação a estes profissionais era quanto ao tempo do seu envolvimento em ELT. Para a visualização desta informação, foi elaborada uma imagem gráfica que a apresenta de forma estratificada:

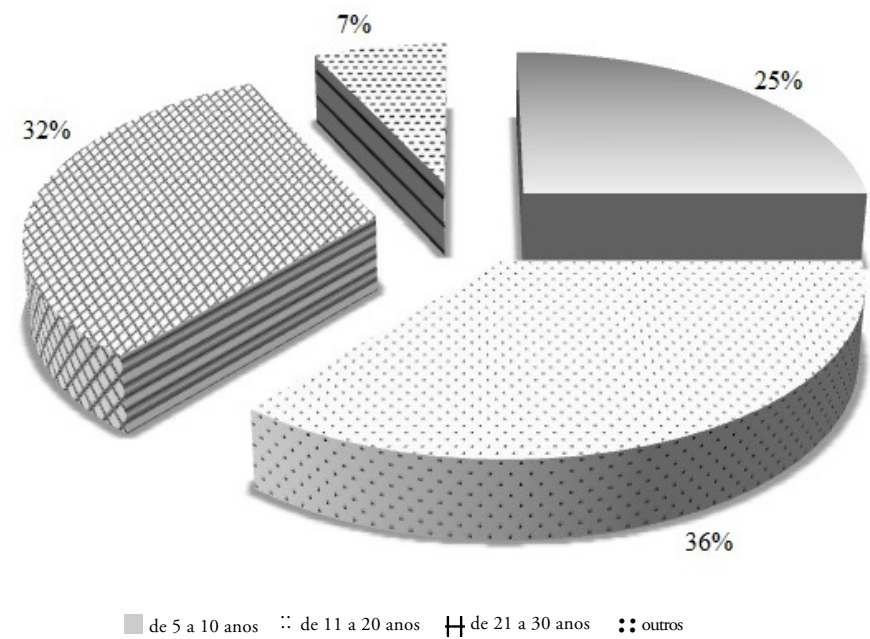

FIGURA 4 - Resposta à pergunta "How long have you been involved in ELT?" 
Através desta estratificação foi possível observar que do total de respondentes, $68 \%$ atuam em ELT entre 11 e 30 anos. Com essa constatação, procurou-se verificar através das informaçōes fornecidas pelos colaboradores quais os seus âmbitos de atuação. Observou-se, assim, que 40\% (dos 68\%) dos respondentes atuam no ensino regular (Figura 5). Esta informação é especialmente relevante para este estudo uma vez que estes profissionais atuam nos contextos diretamente afetados pelas políticas educacionais. Nesse sentido, penso que é necessário levar em consideração a relevância das demandas da sociedade contemporânea, que quer ver cumprir as tarefas que têm sido propostas por linguistas e estudiosos das línguas/linguagens (RODRIGUES, 1966; BAGNO; RANGEL, 2005; VANDRESEN, 1973 e 1997 (apud ZILLES; FARACO, 2006); ZILLES; FARACO, 2006; FARACO, 2007).
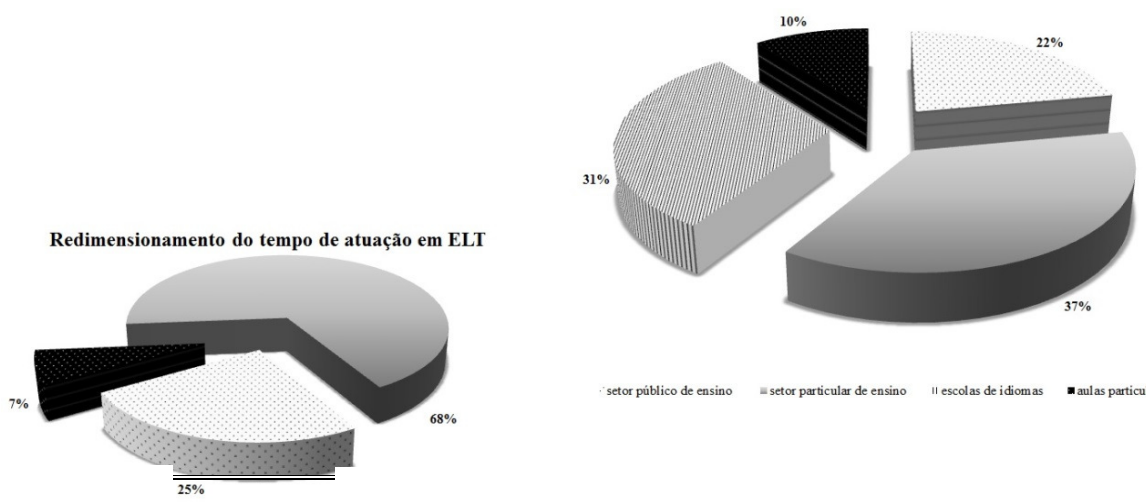

FIGURA 5 - Tempo de atuação em ELT em relação ao âmbito de atuação docente

Outro resultado que pôde ser constatado a partir da análise das respostas diz respeito às faixas etárias atingidas pelos colaboradores do estudo. A esmagadora maioria dos respondentes atua no ensino de adolescentes, jovens adultos e adultos, como pode ser visto na Figura 6. Essa faixa etária é aquela que compõe a grande parte da população que está ativa e intelectualmente receptiva aos desafios da área das linguagens, das tecnologias, enfim, da semiótica em geral. Apesar de muitas iniciativas já estarem ocorrendo nos níveis médios e universitários no Brasil, ainda há muito a ser feito. Professores de ensino superior e acadêmicos podem aplicar seus conhecimentos e compartilhá-los entre si, com seus alunos e com a sociedade em geral, aprofundando os achados da área das línguas através do amparo científico oriundo dos estudos e das investigações advindas da Linguística Educacional. 
Por curiosidade, ao final da análise descrita acima, foi verificada a relação entre o tempo de atuação dos professores e as faixas etárias com as quais os respondentes informaram atuar. Essa análise foi feita levando em consideração o fato de que muitos dos colegas que receberam a solicitação de contribuir com o estudo atuam no ensino superior.

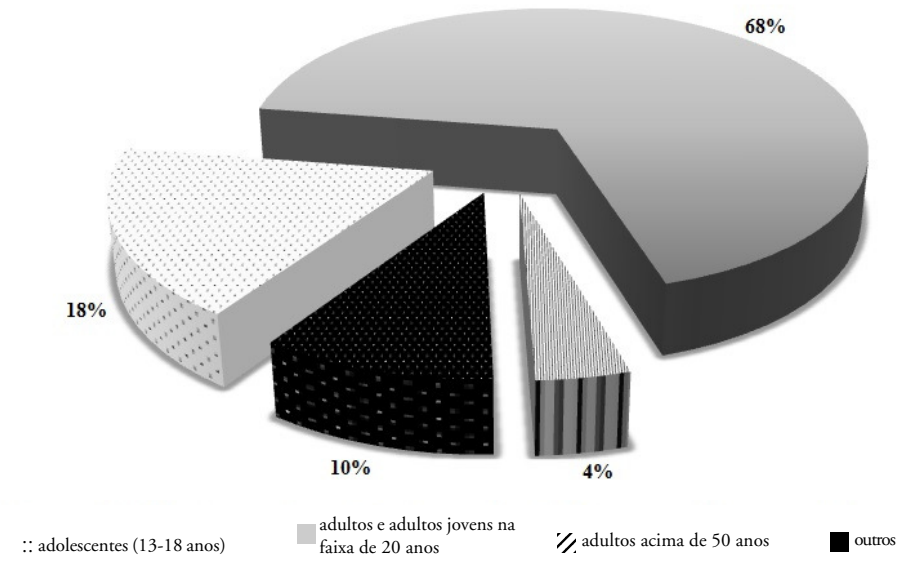

FIGURA 6 - Respostas à pergunta “What is your students' main age range?”

Assim, e mesmo não podendo afirmar conclusivamente, há uma forte possibilidade de que $58 \%$ dos $68 \%$ dos respondentes que atuam no ensino regular (público ou particular) possam estar em contato com acadêmicos dos mais diversos cursos universitários - considerando que em muitas instituições a língua inglesa é componente curricular de muitas grades curriculares, o que reforça a nossa responsabilidade na formação dos futuros professores de línguas.

Finalmente, e com relação à última indagação do questionário - Which ELT aspects do you consider of main importance in your teaching? (you may inform more than one item) -, os colaboradores responderam sobre os itens de ensino da língua inglesa, propriamente. 


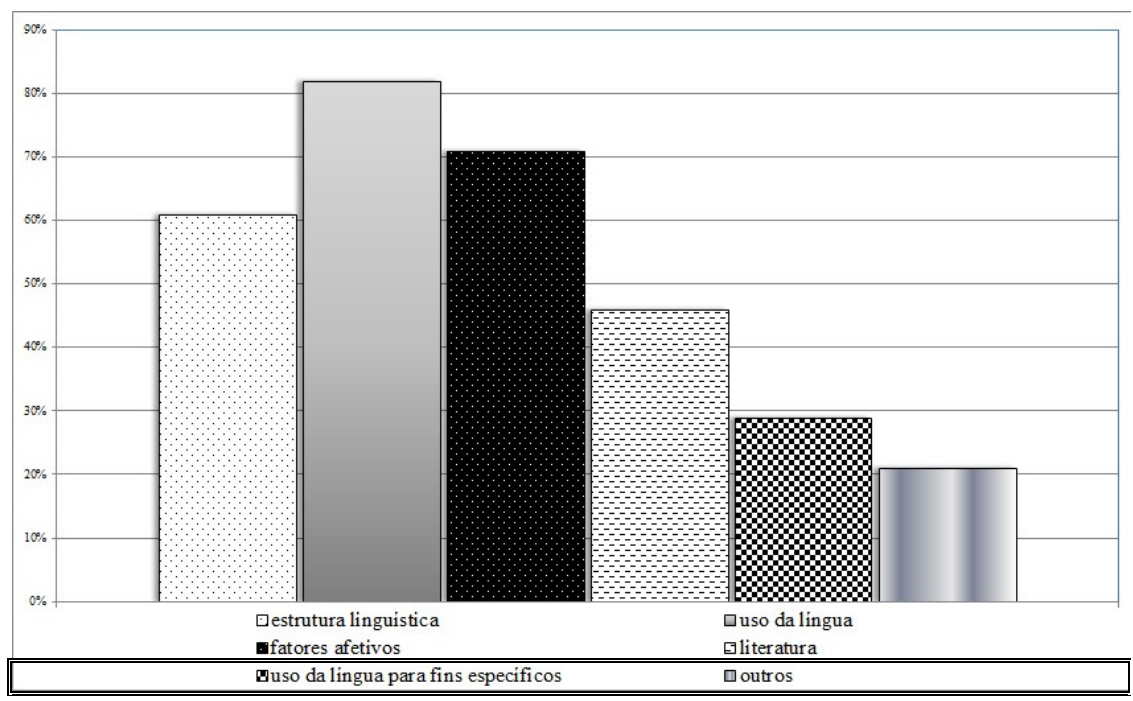

FIGURA 7 - Aspectos de ELT considerados importantes pelos respondentes

A Figura 7 apresenta os itens oferecidos no questionário e os respectivos percentuais de referência fornecidos pelos colaboradores do estudo. É interessante observar que o item 'uso da língua' foi apontado por $82 \%$ dos respondentes, o que, mais uma vez, sugere a necessidade de os formadores contemplarem os aspectos relacionados à educação linguística como parte explícita do currículo, especialmente na formação de futuros professores de línguas. Neste caso, como a língua em questão é o inglês, pode-se inferir que os respondentes se referiam ao uso eficaz da língua, através da instrução formal e do ensino de itens pontuais da língua inglesa - o que não exclui sumariamente a referência a outras línguas, considerando que alguns dos colegas que foram chamados a participar do estudo, apesar de graduados em inglês, atuam também na formação de professores de português e de espanhol. Essa inferência decorre da análise do item 'estrutura linguística', assinalado por $61 \%$ dos professores. Além dos itens relacionados ao uso e às estruturas linguísticas, propriamente, $71 \%$ dos professores responderam que os fatores afetivos também são muito importantes em suas práticas. Esse item foi referido no questionário em relação às motivações dos alunos para aprender a língua inglesa.

Ainda quanto à análise dos itens elencados na Figura 7, pode-se considerar que o ensino de línguas, da forma como os respondentes o compreendem, está inextricavelmente relacionado a aspectos estruturais, afetivos e de uso, o que configura um avanço, se considerarmos que muitas experiências compartilhadas frequentemente se referem às agruras do ensino, 
redundando não somente no descrédito da atuação dos professores de línguas na educação formal básica, mas também na baixa procura de candidatos à docência de línguas.

Da mesma forma, a educação de professores de línguas deve contemplar esses aspectos - os estruturais, os afetivos e os de uso - no sentido de promover ações através da interação com os textos que apresentam as políticas oficiais de ensino (BAGNO; RANGEL, 2005, 67). Desta perspectiva, é crucial que os acadêmicos tenham contato com as reflexões propostas pelos documentos e também com materiais didáticos que, quando analisados tecnicamente, podem contribuir para a ampliação do entendimento das teorias e das propostas pedagógicas que sustentam o trabalho dos autores. Através de visão crítica e fundamentada, os alunos poderão, já a partir da sua formação, sentirem-se eles também sujeitos de suas práticas e, assim, contribuírem para a educação linguística de seus alunos de forma coerente.

$\mathrm{O}$ item 'literatura', apresentado no questionário com uma nota a referências literárias e culturais, foi assinalado por $46 \%$ dos respondentes. Este item, juntamente com a proposta do ensino de língua para fins específicos (contemplado por 29\% dos respondentes), é associado muitas vezes à leitura, inclusive pelos Referenciais. Entretanto, como a leitura costuma ser insumo para a escrita, entende-se que no caso das línguas adicionais a produção escrita pode ser administrada a partir da exploração de gêneros discursivos que, por sua vez, proporcionariam formas de aplicação do conhecimento escolar em práticas linguísticas futuras. Para a educação linguística, da forma como os Referenciais propõem, o texto é a matéria-prima para a aula de línguas adicionais. Além disso, a ênfase na proficiência da leitura, da escrita e da resolução de problemas encontra, na literatura e no estudo de textos para fins específicos, o amparo dos Referenciais no sentido de desenvolver essas competências, conforme especificado:

- $\quad$ ler - (re)agir e posicionar-se criticamente frente a diferentes textos (orais e escritos);

- $\quad$ escrever - produzir textos com determinados propósitos para determinados interlocutores e, assim, poder inserir-se de modo mais participativo na sociedade; e

- resolver problemas, em dois âmbitos complementares: por um lado, enfrentar os desafios de cada novo encontro com a leitura e escrita do texto; por outro, mobilizar os sentidos construídos e os pontos de vista de cada texto para a expressão de si, a compreensão da realidade e para lidar com 
diferentes atividades pessoais e coletivas de forma informada, crítica e responsável. (RIO GRANDE DO SUL, 2009, 135)

Outros aspectos de ELT que foram considerados importantes na prática docente de $21 \%$ dos professores participantes foram relacionados à utilização de música para o ensino de inglês, às estratégias de aprendizagem, às questões teóricas relacionadas a metodologias, ao uso de estratégias de polidez e ao ensino explícito de gêneros.

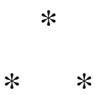

Das respostas obtidas às indagações deste estudo, da análise das questões propostas e das limitações da utilização do questionário apresentado aos respondentes decorrem algumas ponderaçóes necessárias. Primeiramente, cabe a menção quanto à restrição dos resultados, que não devem ser tomados como generalizações, mas como identificação de tendências possíveis para a amostra selecionada.

Em segundo lugar, a própria amostra de respondentes pode ter sido influenciada pelo envio nominal de uma solicitação explicitamente intimativa - "ifyou are receiving this e-mail you are definitely one of them ..." - e justificada por uma resposta ao apelo à solidariedade entre pares - "As you know, I am currently working on my $\mathrm{PhD}$ and ... ". Provavelmente tais aspectos justifiquem a atenção que o estudo recebeu de $70 \%$ dos possíveis respondentes selecionados inicialmente, o que, para um estudo quantitativo, ainda que de pequena monta, permanece um retorno muito bom. De qualquer forma, as respostas foram obtidas e analisadas de maneira criteriosa e as contribuições, informadas anonimamente, reiteram a legitimidade dos dados e das respectivas análises.

Ainda que as questôes relacionadas às perguntas postas e à análise dos dados tenham recebido tratamento meticuloso, o meio elaborado para os fins da geração dos dados deste estudo permanece um instrumento limitado na medida em que, por tratar-se de questionário fechado, pode ter restringido a manifestação dos colaboradores quanto ao seu conhecimento mais aprofundado sobre o tema. Ainda que o espaço da questão aberta tenha proporcionado algumas manifestações da parte dos colaboradores, o tratamento quantificado dos dados pode não ter propiciado espaço suficiente para que os conhecimentos dos colaboradores do estudo fossem percebidos de forma mais explícita e clara. Permanece, assim, a necessidade de estudos que possam aprofundar tais questóes relacionadas ao presente tópico. 


\section{Considerações finais e uma [outra] tarefa}

Para esclarecer a ideia de educação linguística que quis compartilhar com o leitor é preciso que tenhamos em mente que educação linguística é tudo o que foi escrito e lido até aqui. É também a condição de escrever e de ler textos, como estamos fazendo neste exato momento. Mormente, a educação linguística deve ser proveniente da nossa condição de falantes de uma ou de mais línguas e, em decorrência disso, de nos tornarmos capazes de perceber que é possível elaborar, reconstruir e pôr em prática as nossas ações linguisticamente informadas. Nessa perspectiva a educação linguística é, portanto, um aprendizado contínuo que se origina em diferentes âmbitos e, necessariamente, nos outorga responsabilidades provenientes de escolhas feitas. [Sim, aqui eu direciono minhas palavras aos meus colegas educadores de língua inglesa e aos acadêmicos da área.]

Tomarmos para nós a responsabilidade de interferirmos de forma mais contundente na educação de nossos alunos deve ser, portanto, mais uma das tantas tarefas já sugeridas por colegas, linguistas, intelectuais, estudiosos e professores que marcaram a nossa formação escolar e acadêmica.

Ocorre que com essa tarefa, vem também a necessidade de conhecermos mais este objeto de estudo e os seus aprendizes. Assim, as investigações relacionadas à educação linguística (objeto de estudo) devem ser cada vez mais aprofundadas no sentido de proporcionarem a clareza necessária àqueles que precisam interagir em um mundo que é de todos. Nossos alunos (tanto os acadêmicos quanto os jovens da educação básica) têm o direito de receber o conhecimento que lhes conduzirá a uma inserção ampliada no mundo globalizado em que vivem. Para isso, devem ter o domínio dos instrumentos formais e cidadãos para reivindicar a sua participação e atuação neste universo - até porque isso lhes é cobrado diariamente através dos desafios da sociedade contemporânea. Nesse sentido, a Linguística Educacional pode contribuir enormemente através da educação linguística.

Sendo assim, muito antes de este ser o parágrafo final deste texto, ele pode ser, na verdade, o ponto inicial de uma tarefa que inclui não somente a educação linguística, como empreendimento da Linguística Educacional, subárea da LA, mas a ampliação deste conhecimento que, uma vez expandido, abrange questões sobre letramentos, avaliações, níveis de proficiência, entre tantos outros tópicos passíveis de pesquisa e de mais investigaçôes acadêmicas. 


\section{Agradecimentos}

As considerações sobre a importância do aprofundamento da educação linguística na formação de professores de línguas foram tema das aulas que fizeram parte do programa de doutoramento em Linguística Aplicada, na UNISINOS, e foram, muitas vezes - e no meu caso -, "novidades" debatidas entre colegas ao longo dos encontros coordenados pela Professora Ana Stahl Zilles. Agradeço à Ana pelas valorosas indicações bibliográficas, pelo acolhimento às "perguntas ignorantes" e pelo incentivo às discussões que ocorreram em um momento em que o tema estava em ebulição na mídia e no meio acadêmico. Agradeço, ainda, aos três pareceristas anônimos da RBLA pelas inestimáveis contribuições e pela oportunidade de maior entendimento das questôes tratadas neste artigo; os equívocos que porventura permaneçam são de minha inteira responsabilidade.

\section{Referências}

AMARAL, Luís Centeno do; DUARTE, Nóris Eunice W. P. O professor de língua portuguesa moderno e o discurso escolar anacrônico. Calidoscópio. v. 5, n. 1, p. 15-18, São Leopoldo, jan./abr., 2007.

ASSIS-PETERSON, Ana Antônia; COX, Maria Inês Pagliarini. Inglês em tempos de globalização: para além do bem e do mal. Calidoscópio. v. 5, n. 1. p. 5-14. São Leopoldo, jan./abr. 2007.

BAGNO, Marcos; RANGEL, Egon. Tarefas da educação linguística no Brasil. Revista Brasileira de Linguistica Aplicada, v. 5, p. 63-82. 2005.

BARTELS, Nat. Applied Linguistics and Language Teacher Education. Boston: Springer. 2005.

BLOCK, David. Globalization and language teaching. ELT Journal. v. 58, n. 1. Oxford University Press, jan., 2004.

BOLITHO, Rod. Language Awareness in the English classroom. English Teaching Professional. Pavillion, (6). p. 3-6, 1998.

BRASIL, Ministério da Educação, Secretaria de Educação Básica. Orientações curriculares para o ensino médio. Brasília: Ministério da Educação, v. 1, p. 239, 2006. BRASIL, Ministério da Educação, Secretaria de Educação Média e Tecnológica. Parâmetros curriculares nacionais, códigos e suas tecnologias. Lingua estrangeira moderna. Brasília: MEC, p 49-63, 1999. 
BRASIL, Ministério da Educação, Secretaria de Educação Média e Tecnológica. PCN+ - Ensino Médio, Orientaçôes Educacionais Complementares aos Parâmetros Curriculares Nacionais. Brasília: MEC-SEMTEC, 2002.

CAVALCANTI, Marilda C. A propósito de Linguística Aplicada. Trabalhos de Linguística Aplicada. n. 7. p. 5-12, 1986.

COX, Maria Inês Pagliarini; ASSIS-PETERSON, Ana Antônia. O drama do ensino de inglês na escola pública brasileira. In: ASSIS-PETERSON, Ana Antônia (Org.). Linguas estrangeiras: para além do método. São Carlos: Pedro \& Joao Editores. Cuiabá: EdUFMT, 2008

FARACO, Carlos Alberto. Guerras em torno da língua: questôes de política linguística. In: FARACO, Carlos Alberto (Org.). Estrangeirismos: guerras em torno da língua. São Paulo: Parábola, 2007.

GARCEZ, Pedro M. Educação Linguística como conceito para a formação de profissionais de língua estrangeira. In: Laura Masello (Org.). Portugués Lengua Segunda y Extranjera en el Uruguay. Montevideo: Universidad de la República/ Departamento de Publicaciones, 2008. p. 51-57.

HUDSON, Richard. Linguistic Theory. In: SPOLSKY, Bernard; HULT, Francis M. (Org.). The Handbook of Educational Linguistics. Wiley-Blackwell, 2008. p.53-65. JUDD, Elliot L.; TAN, Lihua; WALBERG, Herbert J. Teaching additional languages. UNESCO. International Academy of Education. International Bureau of Education, 2003.

KACHRU, Braj B.; KACHRU, Yamuna; NELSON, Cecil L. The handbook of world Englishes. Blackwell Publishing, 2006.

LO BIANCO, Joseph. Educational Linguistics and Education Systems. In: SPOLSKY, Bernard; HULT, Francis M. (Org.). The Handbook of Educational Linguistics. Wiley-Blackwell, 2008. p. 113-126.

LONGARAY, Elisabete Andrade. Globalização, anti-imperialismo e o ensino de inglês na era pós-moderna. Tese (doutorado) - Universidade Federal do Rio Grande do Sul. Instituto de Letras. Programa de Pós-Graduação em Letras. Porto Alegre-RS, 2009. LOPES-ROSSI, Maria Aparecida Garcia. Tendências Atuais da Pesquisa em Linguística Aplicada. Anais do 5o Seminário de Pesquisas em Linguística Aplicada. SePLA. Taubaté: Unitau, 2009.

LUFT, Celso Pedro. Minidicionário Luft. Editora Ática. 12 ed., 1996.

MASSINI-CAGLIARI, Gladis. Language Policy in Brazil: monolingualism and linguistic prejudice. Language Policy, v. 3, n. 23, Kluwer Academic Publishers, 2004. 
MCGROARTY, Mary. The political matrix of linguistic ideologies. In: SPOLSKY, Bernard; HULT, Francis M. (Org.). The Handbook of Educational Linguistics. Wiley-Blackwell, 2008. p. 98-112.

MESTHRIE, Rajend. Sociolinguistics and Sociology of Language. In: SPOLSKY, Bernard; HULT, Francis M. (Org.). The Handbook of Educational Linguistics. Wiley-Blackwell, 2008. p. 66-82.

MOITA LOPES, Luiz Paulo da. Por uma linguística aplicada INdisciplinar. São Paulo: Parábola Editorial. Lingua[gem], 2008.

RAJAGOPALAN, Kanavillil. South American Englishes. In: KACHRU, Braj B.; KACHRU, Yamuna; NELSON, Cecil L. The handbook of world Englishes. Blackwell Publishing, 2006.

RYAN, Patricia. Don't insist on English!TED ideas worth spreading. 2010. Disponível em: <http://www.youtube.com/watch?v=tFX68SJs2-0>. Acesso em: 15 jun. 2013. SCHLATTER, Margarete; GARCEZ, Pedro M. Treinamento ou Educação no Ensino de Língua: escolha metodológica ou política? In: MENEZES, V., DUTRA, D. P., MELLO, H. (Org.). Anais do VI Congresso Brasileiro de Linguistica Aplicada: A Linguagem como Prática Social. Belo Horizonte, ALAB, 2001. p. 345-378.

SCHLATTER, Margarete; GARCEZ, Pedro M. Linguas adicionais na escola: aprendizagens colaborativas em inglês. Erechim: Edelbra, 2012.

SCHLATTER, Margarete. O ensino de leitura em língua estrangeira na escola: uma proposta de letramento. Calidoscópio, v. 7, n. 1, p.11-23. 2009.

SHIN, Hyunjung; KUBOTA, Ryuko. Post-colonialism and Globalization in Language Education. In: SPOLSKY, Bernard; HULT, Francis M. (Org.). The Handbook of Educational Linguistics. Wiley-Blackwell, 2008. p. 206-218

SPOLSKY, Bernard; HULT, Francis M. The Handbook of Educational Linguistics. Wiley-Blackwell, 2008. p. 53-65

SPOLSKY, Bernard. Introduction: What is Educational Linguistics? In: SPOLSKY, Bernard; HULT, Francis M. (Org.) The Handbook of Educational Linguistics. Wiley-Blackwell. 2008. p. 1-9.

SPOLSKY, Bernard. Language Policy. Procedings of the $4^{\text {th }}$ International Symposium on bilingualism. Ed. James Cohen, Kara T. McAlister, Kellie Rolstad, and Jeff MacSwan. Somerville, MA: Cascadilla Press, 2005. p. 2152-2164.

SPOLSKY, Bernard. The Navajo Reading Study: an illustration of the scope and nature of educational linguistics. In: QUISTGAARD, J.; SCHWARZ, H.; SPONG-HANSSEN, H. (Ed.). Applied Linguistics: Problems and Solutions: Proceedings of the Third Congress on Applied Linguistics, Copenhagen, 1972. v. 3, p. 553-565. Heidelberg: Julius Gros Verlag. 1974b. 
VAN LIER, Leo. Ecological-Semiotic Perspectives on Educational Linguistics. In: Spolsky, Bernard e Hult, Francis M. (Org.). The Handbook of Educational Linguistics. Wiley-Blackwell, 2008. p. 1-9.

VANDRESEN, Paulino. Tarefas da Sociolinguística no Brasil. Revista de Cultura Vozes, v. LXVIII, n. 8, 1973, p. 5-11. 1973.

WIDDOWSON, Henry G. Defining Issues in English Language Teaching. Oxford: OUP, 2003.

ZILLES, Ana M. S. e FARACO, Carlos A. As tarefas da sociolinguística no Brasil: balanço e perspectivas. In: Gorski, Edair M. e Coelho, Izete L. (Org.). Sociolinguistica e ensino - Contribuições para a formação do professor de língua. Florianópolis: Ed. UFSC, 2006. p. 23-52.

Recebido em 06/12/2012. Aprovado em 25/01/2013. 